JAMP: Jurnal Adminitrasi dan Manajemen Pendidikan

Volume 3 Nomor 2 Juni 2020, Hal : 123-130

Tersedia Online di http://journal2.um.ac.id/index.php/jamp/

ISSN 2615-8574 (online)

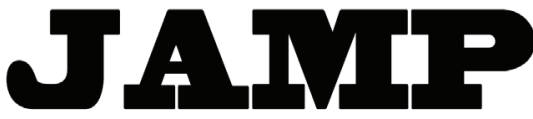

JURNAL ADMINISTRASI DAN MANAJEMEN PENDIDIKAN

\title{
MANAJEMEN SARANA DAN PRASARANA UNTUK MENGEMBANGKAN MUTU PENDIDIKAN
}

\author{
Nur Khikmah \\ UIN Walisongo Semarang, J1. Prof. Hamka Ngaliyan, Kota Semarang 50185 \\ Email: nurkhikmah@walisongo.ac.id
}

\begin{abstract}
The success of educational programs in schools is greatly influenced by the condition of educational facilities and infrastructure. Meeting the needs of infrastructure is aimed at describing and analyzing the planning, organizing, mobilizing, monitoring, supporting and inhibiting factors for infrastructure management to develop the quality of education in MI Kebonharjo, North Semarang. Qualitative research data collection techniques by observation, interview, documentation and triangulation. Data analysis techniques: data collection, data reduction, data presentation and conclusion drawing. The findings of this study are planning with annual meetings, evaluating, reviewing work programs, carrying out program activities and program socialization to parents. Organizing: organizational structure, staffing, job descriptions and responsibilities, communication and coordination. Mobilization by procuring goods, inventory, maintenance, selection, reporting. Supervision by evaluating and supervising as well as follow-up from supervision. Supporting factors: neat design, employee placement, neat filing and the involvement of madrasah supervisors. Inhibiting factors: commitment of each human resource, lack of funds, complicated regulations and lack of employee skills development.
\end{abstract}

Keyword: Infrastructure management, Education quality

\begin{abstract}
Abstrak: Keberhasilan program pendidikan di sekolah sangat dipengaruhi oleh kondisi sarana dan prasarana pendidikan. Pemenuhan kebutuhan sarana prasarana ini bertujuan mendeskripsikan dan menganalisis perencanaan, pengorganisasian, penggerakan, pengawasan, serta faktor pendukung dan penghambat manajemen sarana prasarana untuk mengembangkan mutu pendidikan di MI Kebonharjo Semarang Utara. Teknik pengumpulan data penelitian kualitatif dengan cara observasi, wawancara, dokumentasi dan triangulasi. Teknik analisis data: pengumpulan data, reduksi data, penyajian data dan penarikan kesimpulan. Adapun temuan penelitian ini adalah perencanaan dengan rapat tahunan, evaluasi, mereview program kerja, melaksanakan program kegiatan dan sosialisasi program kepada wali murid. Pengorganisasian: struktur organisasi, penempatan staff, uraian tugas dan tanggung jawab, komunikasi dan koordinasi. Penggerakan dengan mengadakan barang, inventarisasi, perawatan, pemilihan, pelaporan. Pengawasan dengan melakukan evaluasi dan supervisi serta ada tindak lanjut dari pengawasan. Faktor pendukung: perancangan apik, penempatan pegawai, pengarsipan rapi dan keterlibatan pengawas madrasah. Faktor penghambat: komitmen masing-masing sumber daya manusia, minimnya dana, regulasi yang rumit dan kurangnya pengembangan keterampilan pegawai.
\end{abstract}

Kata Kunci: Manajemen Sarana Prasana, Mutu Pendidikan

Proses pembelajaran perlu ditunjang dengan adanya fasilitas pendidikan di sekolah yang lengkap dan baik. Dikarenakan ini akan mendukung keberhasilan program kerja dan program kegiatan sekolah dalam mewujudkan cita-cita pendidikan. Selain itu penggunaan fasilitas pendidikan harus dimaksimalkan secara baik dan sesuai tujuan agar bisa dimanfaatkan lebih lama penggunaan fasilitas pendidikan tersebut untuk mendukung proses pengajaran dalam mewujudkan tujuan pembelajaran (Fuad, 2018). 
Pengelolaan keuangan lebih mudah dibandingkan dengan pengaturan fasilitas pendidikan, itu bisa menjadi kurang efisien, kurang efektif, atau bahkan mungkin gagal sama sekali dikarenakan banyak orang yang terlibat dalam pengelolaan manajemen. Ketika prosedur, sistem pengelolaannya tidak jelas, kemampuan pengelola tidak memadai serta kemauan tidak sesuai harapan akan berakibat pada kesulitan pengelolaan sarana dan prasarana.

Fakta di lapangan bahwa ada lemari di ruang kepala MI Kebonharjo Semarang Utara yang bertuliskan kode 5. Administrasi perlengkapan/barang meliputi: (1) 5.1 Daftar Permintaan Benda; (2) 5.2 Daftar Penerbitan Benda; (3) 5.3 Daftar Penyelidikan Perlengkapan/Benda; (4) 5.4 KIR (Kartu Inventaris Ruangan); (5) 5.5 KIB (Kartu Inventaris Benda) Lahan Tempat; (6) 5.6 (Kartu Inventaris Benda) Bangunan; (7) 5.7 Daftar Inventaris Perlengkapan/Benda; dan (8) 5.8 Daftar Usul Penyediaan Benda. Tulisan tersebut ditempel di depan lemari akan tetapi dokumennya tidak ada semua. Dalam mengelola fasilitas pendidikan bagi sekolah yang tergolong masih berkembang dan kecil, fasilitas pendidikan langsung menjadi tanggung jawab oleh kepala madrasah dan dibantu oleh orang-orang yang berada dalam sekolah tersebut seperti guru, pegawai, staf, pembersih dan menjalankan serta mengelola fasilitas pendidikan.

Berbeda pula ketika sekolah yang sudah besar dan maju, pengelolaan fasilitas pendidikan dipercayakan oleh staf ahli khusus untuk menangani dan bertanggung jawab secara maksimal dalam mengelola sehingga fasilitas pendidikan bisa digunakan untuk mendukung kegiatan pengajaran secara efisien dan efektif. Alat-alat pendidikan yang memerlukan keahlian khusus adalah alat transportasi, laptop, air, listrik, internet, telepon, laboratorium, perpustakaan, koperasi, unit kesehatan sekolah, bagian konsumsi/gizi, dan lain-lain. Semakin besar dan maju sekolah tersebut semakin besar pula tanggung jawab yang harus diemban dan dipikul oleh lembaga pendidikan dalam mengelola dan mengembangkan kegiatan manajemen semakin banyak pula alat-alat pendidikan yang harus disediakan untuk menunjang kegiatan belajar mengajar untuk mewujudkan visi sekolah (Mulyono, 2008).

Sejalan dengan hasil penelitian yang dilakukan oleh Trisnawati, dkk., (2019) yang menyimpulkan bahwa: (1) perencanaan sarana dan prasarana, yaitu dengan menganalisis semua sarana dan prasarana sekolah terlebih dahulu; (2) pengadaan fasilitas dan infrastruktur mengumpulkan data inventaris untuk data sebelumnya dan mengetahui inventaris; (3) pemanfaatan / penggunaan digunakan oleh semua penghuni sekolah, guru dan semua siswa sekolah, pemanfaatan inventaris pendidikan juga harus dipantau secara efektif oleh pihak yang ditunjuk oleh sekolah; (4) pemeliharaan sarana dan prasarana sangat dibutuhkan oleh guru dan siswa agar barang-barang yang dimiliki sekolah selalu di bawah pengawasan dan dipelihara dengan baik; dan (5) penghapusan fasilitas infrastruktur dengan membuat surat proposal ke Dinas Pendidikan sehingga pihak terkait dapat membuat laporan resmi untuk dihapus.

Penelitian ini bertujuan untuk mendeskripsikan dan menganalisis perencanaan, pengorganisasian, penggerakan, pengawasan, faktor pendukung dan faktor penghambat supaya dapat mengukur seberapa besar kontribusi manajemen sarana dan prasarana untuk mengembangkan mutu pendidikan di MI Kebonharjo Semarang Utara.

\section{METODE}

Penelitian ini merupakan penelitian lapangan (field research), yaitu pengumpulan data yang dilakukan dengan penelitian di tempat terjadinya gejala-gejala yang diselidiki. Secara metodologis penelitian ini bersifat deskriptif kualitatif, yaitu penelitian yang menghasilkan data deskriptif berupa kata-kata tertulis atau lisan dari orang-orang dan perilaku yang diamati (Arikuto, 2006). Data yang didapatkan peneliti dalam penelitian ini diperoleh dengan memakai teknik: metode observasi, metode wawancara, metode dokumentasi, dan metode triangulasi data

Pemeriksaan keabsahan data yang digunakan merupakan ukuran dasar penilaian untuk melakukan pengecekan data kualitatif (Moleong, 1993). Ukuran tersebut adalah: derajat kepercayaan (credibility), keteralihan (transferbility), kebergantungan (dependability) dan kepastian (confirmability). Proses penyelidikan terhadap suatu peristiwa untuk mengetahui keadaan sebenarnya dalam data kualitatif, 
dilaksanakan ketika pengerahan data terjadi, serta sesudah berakhir pengerahan data dalam kurun waktu tertentu. Analisis data yang digunakan merupakan proses analisis data dari Miles and Huberman (dalam Sugiyono, 2012), yang terdiri dari reduksi data, penyajian data, dan kesimpulan/pemeriksaan tentang kebenaran laporan.

\section{HASIL DAN PEMBAHASAN}

\section{Perencanaan Sarana dan Prasarana}

Sekolah dalam menyelenggarakan adanya fasilitas pendidikan harus mempertimbangkan fasilitas pendidikan sesuai dengan peraturan perundang-undangan yang berlaku tentang standar fasilitas pendidikan yang harus dimiliki oleh setiap sekolah. Proses perancangan wajib menyertakan agar dapat menyelesaikan lima masalah: (1) apa yang dilakukan; (2) mengapa dilakukan; (3) bagaimana dilakukan; (4) dimana dilakukan; dan (5) kapan dilakukan. Sebab perancangan rapi hendak menjalankan proses visi dan misi perusahaan yang ingin digapai. Spizer (dalam Munir dan Wahyu, 2006) mengatakan those who fail to plan, plan to fail (siapa yang tidak berhasil dalam mengerjakan rancangan, sesungguhnya ia sedang merancang ketidak berhasilannya).

Dalam perancangan keperluan sekolah tahap-tahap yang kami jalankan dimulai dengan mengadakan rapat pada bulan Juli setiap tahun awal pelajaran baru dimana agenda tahunan seperti evaluasi program, melaksanakan Penerimaan Peserta Didik Baru (PPDB), membuat program, review KTSP, melaksanakan pembelajaran, sosialisasi program pembelajaran kepada wali murid, pesantren ramadhan halal bihalal seperti yang diungkapkan oleh Ibu Mei Ilmayani, M.Pd.I selaku Kepala MI Kebonharjo Semarang Utara. Adapun program kerja sekolah dalam bidang fasilitas pendidikan dalam rangka pengembangan kualitas pendidikan di MI Kebonharjo Semarang Utara ditampilkan pada Tabel 1.

Tabel 1 Program Kerja MI Kebonharjo Semarang Utara Tahun Pelajaran 2018/2019

\begin{tabular}{|c|c|c|}
\hline \multicolumn{3}{|c|}{ BIDANG SARANA PRASARANA } \\
\hline Jenis Kegiatan & Sasaran yang Ingin Dicapai & $\begin{array}{l}\text { Rencana } \\
\text { Waktu }\end{array}$ \\
\hline \multirow[t]{2}{*}{$\begin{array}{l}\text { Pemeliharaan } \\
\text { Ruang Kepala } \\
\text { Sekolah }\end{array}$} & $\begin{array}{l}\text { 1. Memelihara kebersihan dan keindahan. } \\
\text { 2. Mengganti dan memperbaiki peralatan yang mengalami } \\
\text { kerusakan. }\end{array}$ & \\
\hline & 3. Menambah dan melengkapi peralatan yang masih kurang. & \\
\hline \multirow{4}{*}{$\begin{array}{l}\text { Pemeliharaan } \\
\text { Ruang Guru }\end{array}$} & 1. Memelihara kebersihan, keindahan dan keserasian. & \\
\hline & $\begin{array}{l}\text { 2. Mengganti dan memperbaiki peralatan yang mengalami } \\
\text { kerusakan. }\end{array}$ & \\
\hline & 3. Menambah dan melengkapi peralatan yang masih kurang. & \\
\hline & 4. Menyediakan papan data, papan pengumuman dan atribut. & \\
\hline \multirow{3}{*}{$\begin{array}{l}\text { Pemeliharan ruang } \\
\text { Tata Usaha }\end{array}$} & 1. Memelihara kebersihan, keindahan dan keserasian. & \\
\hline & 2. Melengkapi data-data. & \\
\hline & $\begin{array}{l}\text { 3. Menata peralatan dan pengarsipan untuk memudahkan } \\
\text { pelayanan. }\end{array}$ & \\
\hline \multirow{4}{*}{$\begin{array}{l}\text { Pemeliharaan } \\
\text { Ruang Kelas }\end{array}$} & 1. Memelihara kebersihan, keindahan dan keserasian ruang kelas. & \\
\hline & 2. Memelihara kebersihan meja dan kursi. & \\
\hline & 3. Melengkapi atribut kelas. & \\
\hline & 4. Menata tembok dengan data dan hiasan. & \\
\hline \multirow{3}{*}{$\begin{array}{l}\text { Pemeliharaan Ruang } \\
\text { Laboratorium }\end{array}$} & 1. Memelihara kebersihan, kerapian ruang. & \\
\hline & 2. Penataan dan penyimpanan alat. & \\
\hline & 3. Penggunaan yang baik untuk memperpanjang usia pakai. & \\
\hline
\end{tabular}




\section{BIDANG SARANA PRASARANA}

\begin{tabular}{|c|c|c|}
\hline Jenis Kegiatan & Sasaran yang Ingin Dicapai & $\begin{array}{c}\text { Rencana } \\
\text { Waktu }\end{array}$ \\
\hline $\begin{array}{l}\text { Pemeliharaan Ruang } \\
\text { Perpustakaan }\end{array}$ & $\begin{array}{l}\text { 1. Memelihara kebersihan, kerapian ruang. } \\
\text { 2. Menata kembali buku yang sudah selesai dibaca. } \\
\text { 3. Memperbaiki dan mengganti jilid buku yang sudah rusak. } \\
\text { 4. Memperbaiki dan menambah peralatan yang sudah rusak. } \\
\text { 5. Mengelola buku kunjungan dengan baik. }\end{array}$ & \\
\hline $\begin{array}{l}\text { Pemeliharan } \\
\text { Gedung Bangunan }\end{array}$ & $\begin{array}{l}\text { 1. Memelihara gedung dari kemungkinan bocor dan rusak. } \\
\text { 2. Pengecatan dinding yang kotor. } \\
\text { 3. Penggantian kusen yang lapuk. } \\
\text { 4. Perbaikan plafon yang rusak. } \\
\text { 5. Penggantian kaca yang pecah. }\end{array}$ & \\
\hline $\begin{array}{l}\text { Pemeliharan } \\
\text { Halaman dan Kebun }\end{array}$ & $\begin{array}{l}\text { 1. Memantapkan pelaksanaan kebersihan di lingkungan sekolah. } \\
\text { 2. Pembabatan rumput yang panjang. } \\
\text { 3. Melaksanakan perindangan dan penghijauan. } \\
\text { 4. Penggantian tanaman yang mati. }\end{array}$ & \\
\hline $\begin{array}{l}\text { Pemeliharaan } \\
\text { Musholla }\end{array}$ & $\begin{array}{l}\text { 1. Pemeliharaan dan pengecatan. } \\
\text { 2. Pemeliharaan dan penggantian peralatan. } \\
\text { 3. Penambahan sarana yang kurang. } \\
\text { 4. Pemeliharaan kebersihan lingkungan dan air wudhu. }\end{array}$ & \\
\hline $\begin{array}{l}\text { Pemeliharaan WC } \\
\text { dan Urinoir }\end{array}$ & $\begin{array}{l}\text { 1. Menjaga kebersihan. } \\
\text { 2. Perbaikan sanitasi. } \\
\text { 3. Pengecatan dan perbaikan. }\end{array}$ & \\
\hline $\begin{array}{l}\text { Pemeliharan Alat } \\
\text { Meubelair }\end{array}$ & $\begin{array}{l}\text { 4. Menyediakan alat-alat untuk keperluan WC. (Ember, Gayung } \\
\text { dan Karbol). } \\
\text { 5. Penyedotan septic tank yang sudah penuh. } \\
\text { 1. Pemeliharaan alat-alat meubelir. } \\
\text { 2. Memperbaiki yang rusak. } \\
\text { 3. Menyimpan sisa peralatan yang tidak terpakai. } \\
\text { 4. Menambah peralatan yang kurang. } \\
\text { 5. Memiliki daftar inventaris untuk tiap kelas dan kurang. }\end{array}$ & \\
\hline
\end{tabular}

Perancangan fasilitas pendidikan di MI Kebonharjo Semarang Utara dilakukan dengan mengadakan rapat, kemudian melakukan evaluasi program, membuat program, mereview program, mensosialisasikan program kerja sekolah. Perancangan yang dilakukan oleh MI Kebonharjo Semarang Utara sesuai dengan yang diungkapkan Jones (dalam Sulistyorini, 2009) bahwa perancangan pemenuhan fasilitas pendidikan di sekolah harus dimulai dengan mengevaluasi dan menganalisis jenis pengalaman pendidikan yang diprogramkan sekolah di tahun sebelumnya. Setelah itu diambil tindakan dengan menggunakan kelebihan itu untuk lebih ditingkatkan lagi dalam program pada tahun berjalan.

\section{Pengorganisasian Sarana dan Prasarana}

Pengorganisasian ialah menempatkan ikatan perilaku yang membawa hasil antarpersonalia, akibatnya mereka bisa bekerja sama secara tepat, cermat, berdaya guna dan mendapatkan kesimpulan pribadi dalam menjalankan tugas-tugas dalam keadaan lingkungan yang ada guna mencapai tujuan dan sasaran tertentu. MI Kebonharjo Semarang Utara dalam tahapan ini menempatkan guru-guru sesuai dengan kompetensinya dan keahliannya. Selain itu juga dalam memberlakukan pembagian kerja di MI Kebonharjo Semarang Utara masih menggunakan rangkap jabatan/rangkap pekerjaan bagi semua guru begitu pula berlaku juga bagi kepala madrasah. 
Pembagian pekerjaan yang diberlakukan di MI Kebonharjo Semarang Utara adalah guru selain sebagai wali kelas juga merangkap sebagai penanggung jawab ruang/kelas untuk menjaga, merawat semua yang ada dikelasnya masing-masing. Selain itu juga guru harus melaksanakan kegiatan pengajaran, pembelajaran, pelatihan dan bimbingan kepada peserta didik. Kepala madrasah kadangkala juga merangkap sebagai guru bimbingan konseling bahkan guru pengganti kelas untuk menggantikan tugas guru yang sedang berhalangan hadir ke sekolah. Selain itu juga dalam mengarsipkan semua barang yang ada di masing-masing ruangan juga menjadi tugas guru selaku penanggung jawab ruang/kelas.

Tahap-tahap pengorganisasian yang dilakukan MI Kebonharjo Semarang Utara meliputi: (1) mengetahui tujuan kelembagaan; (2) menentukan aktivitas-aktivitas yang dibutuhkan untuk menggapai tujuan kelembagaan; (3) aktivitas yang sekelompok (sejenis) dikumpulkan dalam satu unit kerja; (4) menentukan fungsi, tugas, wewenang, tanggung jawab setiap unit kerja; (5) menentukan personal (jumlah dan keahliannya) setiap unit kerja; dan (6) menetapkan hubungan kerja antarunit kerja.

Pada kegiatan tahap pengorganisasian fasilitas/alat pendidikan dalam rangka pengembangan kualitas pendidikan di MI Kebonharjo Semarang Utara dilakukan dengan cara menyusun struktur organisasi bagian fasilitas pendidikan di MI Kebonharjo Semarang Utara dengan menempatkan sumber daya manusia sesuai dengan kompetensi dan keahliannya, menguraikan tugas dan kewajiban serta wewenang dan haknya, bertanggungjawab untuk melaksanakan tugas pokok dan fungsi yang diamanahkannya serta bekerja sama untuk berkomunikasi dan berkoordinasi dengan sumber daya manusia yang lain untuk melaksanakan tugas, tanggung jawab tersebut demi mewujudkan cita-cita MI Kebonharjo Semarang Utara.

MI Kebonharjo Semarang Utara menerapkan tipe pengorganisasian lini dan staf. Ciri-ciri pengorganisasian lini dan staf adalah: (1) organisasinya tidak kecil; (2) ikut serta dalam perjalanan rangkaian aktivitas yang kompleks; (3) jumlah pegawai yang tidak sedikit dengan kemampuan serta kecakapan pengetahuan dan keterampilan yang bervariasi: dan (4) pimpinan dan bawahan memiliki hubungan kerja yang bersifat tidak langsung, baik disebabkan jumlah sumber daya manusia dalam organisasi yang tidak sedikit, atau disebabkan tempat yang berbeda dan berjauhan (Siagian, 2012). Dibutuhkan tingkat keahlian dan kecakapan manajerial dan teknis operasional yang tinggi dalam pelaksanaan berbagai kegiatan yang bermacam-macam. Berikut struktur organisasi sarana prasarana di MI Kebonharjo Semarang Utara (Gambar 1).

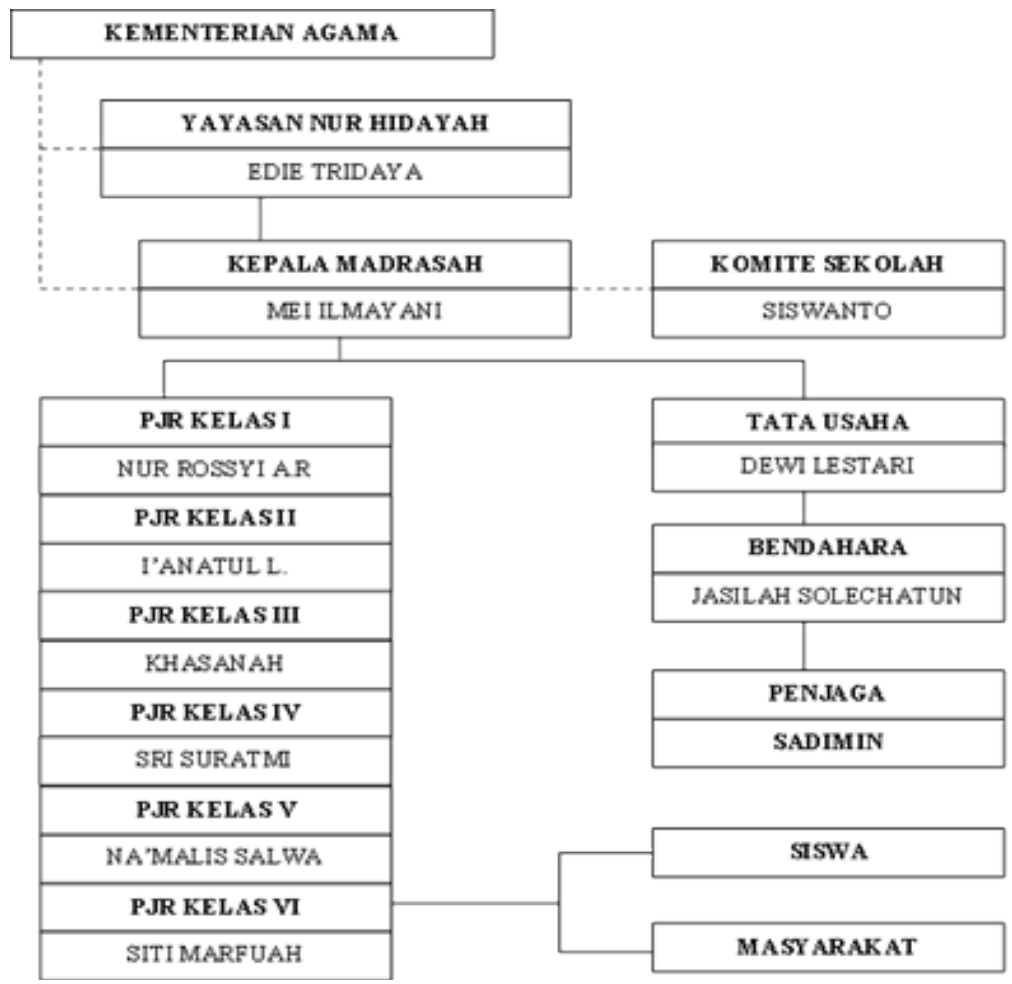

Gambar 1 Struktur Organisasi Sarana Prasarana MI Kebonharjo Semarang Utara 


\section{Penggerakan Sarana dan Prasarana}

Kegiatan mengerahkan pikiran, tenaga di antara sumber daya manusia baik yang terlibat ataupun tidak terlibat melalui kerjasama melaksanakan aktivitas-aktivitas yang sudah dirancang untuk membuat organisasi tersebut dapat mewujudkan tujuan secara efektif dan efisien. Tahapan ini juga merupakan salah satu rangkaian dari beberapa tahap fungsi manajemen. Fungsi Penggerak dan pelaksanaan dalam istilah lainnya yaitu: motivating (mengangkat semangat); directing (menentukan arah); influencing (mempengaruhi); dan commanding (memberikan komando atas perintah) (Siagian, 2012).

Program kerja MI Kebonharjo Semarang Utara menyebutkan bahwa dalam tahun ajaran 2018/2019 ini pengadaan fasilitas pendidikan lebih difokuskan pada kegiatan pemeliharaan seperti pemeliharaan ruang kepala sekolah, pemeliharaan ruang guru, pemeliharaan ruang tata usaha, pemeliharaan ruang kelas, pemeliharaan ruang laboratorium, pemeliharaan ruang perpustakaan, pemeliharaan gedung bangunan, pemeliharaan halaman dan kebun, pemeliharaan musholla, pemeliharaan water closed (wc) dan urinoir, serta pemeliharaan alat meubelair.

MI Kebonharjo Semarang Utara juga mengikuti langkah-langkah kegiatan inventarisasi yang diungkapkan oleh Bafadal (2000), diantaranya: (1) pembukuan perlengkapan pendidikan di dalam buku penerimaan barang; (2) penggunaan kode khusus untuk alat yang tergolong barang inventaris; dan (3) semua fasilitas pendidikan di sekolah yang termasuk dalam barang inventaris dicatat dan dilaporkan.

Peniadaan fasilitas pendidikan dilakukan berdasarkan barang atau alat yang sudah tidak layak dipakai ditempatkan pada tempat dipojok kelas karena gudang sekolah sudah tidak muat untuk menampungnya kemudian guru sekaligus penanggungjawab ruang akan melaporkan kepada kepala madrasah untuk segera ditindak lanjuti dan diteruskan untuk disampaikan ke yayasan apakah barang tersebut masih bisa diperbaiki atau langsung dilakukan penjualan barang.

Kegiatan penggerakan manajemen sarana dan prasarana untuk mengembangkan mutu pendidikan di MI Kebonharjo Semarang Utara di antaranya adalah: (1) mengadakan barang ketika mendesak dan penting serta harus ada tanpa melihat dari program kerja yang sudah ditentukan dan disahkan; (2) melakukan inventarisasi dan perawatan; (3) pemilihan barang yang masih layak digunakan dan yang tidak layak digunakan; (4) penanggungjawab ruang/kelas melaporkan kepada kepala sekolah dan diteruskan dengan melapor kepada yayasan untuk meminta keputusan tindakan lanjutan yang harus ditempuh; dan (5) mendapatkan keputusan dari yayasan dengan syarat diperbaiki jika masih bisa, dan dijual jika tidak bisa lagi untuk diperbaiki.

\section{Pengawasan Sarana dan Prasarana}

Handayaningrat (2007) mengatakan bahwa pengawasan diartikan sebagai usaha menentukan apa yang sedang dilaksanakan dengan cara menilai hasil atau prestasi yang dicapai dan kalau terdapat penyimpangan dari standar yang telah ditentukan, maka segera diadakan usaha perbaikan, sehingga semua hasil atau prestasi yang dicapai sesuai dengan rencana.

Pengendalian fasilitas pendidikan dalam rangka pengembangan kualitas pendidikan di MI Kebonharjo Semarang Utara adalah melakukan koordinasi dan komunikasi dengan penanggungjawab ruang/kelas bersama kepala sekolah menentukan program, rencana program pemantauan, penjadwalan pengawasan, kemudian meminta setiap penanggungjawab ruang/kelas mencatat secara rapi dan teratur dalam buku sesuai daftarnya masing-masing serta melaporkan kepada kepala sekolah. Selain itu juga kepala sekolah meminta bantuan kepada pengawas madrasah untuk memantau dan menilai hasil kinerja semua guru ataupun penanggungjawab ruang atau kelas dan memberikan saran serta masukan. Kemudian kepala sekolah menyampaikan kembali masukan dari pengawas kepada guru sekaligus penanggungjawab ruang untuk segera dilakukan tindak lanjut supaya tidak terulang kembali di tahun depan.

Sejalan dengan pernyataan dan observasi yang disampaikan dan dilakukan oleh semua guru sekaligus penanggungjawab ruang/kelas bahwa kami harus berkoordinasi serta menjalin komunikasi untuk menentukan program, rencana program pemantauan, penjadwalan pengawasan, kami akan diamati dan dinilai oleh pengawas baik terkait cara memberi pengajaran kepada peserta didik serta melihat 
buku administrasi kami sesuai tugas yang kami emban. Kemudian pengawas memberikan masukan, melakukan pengesahan dokumen yang sudah diperiksa dan pemberian nilai atas dokumen tersebut.

\section{Faktor Pendukung Manajemen Sarana dan Prasarana}

Faktor pendukung adalah adanya dukungan Dinas Pendidikan terkait, adanya bantuan dari pihak luar seperti dana aspirasi, bantuan dana dari masyarakat/orang tua murid, kerjasama dari seluruh komponen internal sekolah. Siswa dan guru yang dijadikan sebagai alasan mengapa sarana dan prasarana tersebut perlu diadakan, lebih lanjut selain dan dijadikan sebagai faktor penghambat, juga dapat dijadikan faktor pendukung sehingga sarana dan prasarana tersebut dapat diadakan (Prastyawan, 2016).

Faktor pendukung manajemen sarana dan prasarana untuk mengembangkan mutu pendidikan di MI Kebonharjo Semarang Utara antara lain dapat ditemukan: (1) perancangan yang sangat baik dilakukan oleh sumber daya manusia yang ada di sekolah; (2) penempatan sumber daya manusia yang sesuai kompetensinya untuk menduduki jabatan; (3) pengarsipan yang sangat rapi dan terdokumentasikan secara apik; (4) koordinasi dan komunikasi yang terjalin baik antar sesama sumber daya manusia yang menempati posisi karena sedikitnya sumber daya manusia; dan (5) pengawas yang terlibat dalam menilai dan memberikan masukan untuk perbaikan kompetensi sumber daya manusia.

\section{Faktor Penghambat Manajemen Sarana dan Prasarana}

Faktor penghambat manajemen sarana dan prasarana untuk mengembangkan mutu pendidikan di MI Kebonharjo Semarang Utara antara lain dapat ditemukan: (1) komitmen sumber daya manusia yang ada di sekolah untuk merealisasikan program yang sudah disusun dan disepakati; (2) kecenderungan suka melaksanakan program yang insidental serta sifatnya penting, mendesak dan tidak tertulis dalam program kerja sekolah; (3) minimnya anggaran untuk mengalokasikan dan memenuhi semua kebutuhan yang dikeluarkan sekolah selama satu tahun; (4) proses keputusan pengambilan tindakan yang harus menunggu dari kebijakan yayasan; dan (5) kurangnya kesempatan latihan pengembangan keahlian dan kompetensi bagi sumber daya manusia yang ada.

Sejalan dengan Prastyawan (2016) bahwa keterbatasan dana dalam mendukung kegiatan sarana dan prasarana hanya mengandalkan dana BOS, kurangnya birokrasi bantuan pemerintah sedikit lambat dalam penanganan hal sarana dan prasarana. Sekolah hanya menunggu balasan surat permohonan dan data online yang diterima dalam permohonan perbaikan, penambahan, renovasi, perawatan, pemeliharaan kalau hal tersebut di setujui maka sekolah akan dapat bantuan dana. Agar tujuan dapat tercapai maka dibutuhkan kurikulum yang kuat, baik secara infrastruktur maupun suprastruktur, kurikulum gunanya sebagai pedoman dalam kegiatan pembelajaran, dan khususnya interaksi antara pendidik dan peserta didik dalam kegiatan belajar mengajar, serta guru membutuhkan sarana pembelajaran dalam menunjang kegiatan pembelajaran sehingga guru mampu dalam menyelenggarakan pembelajaran.

\section{SIMPULAN}

Temuan yang dapat diuraikan dari hasil penelitian ini antara lain sebagai berikut. Perencanaan meliputi melakukan rapat tahunan ajaran baru setiap bulan juli, melaksanakan evaluasi program tahun sebelumnya, membuat program kerja sekolah untuk tahun berjalan, mereview program kerja sekolah yang akan dilaksanakan pada tahun berjalan, serta melaksanakan dan mensosialisasikan program kepada wali murid.

Pengorganisasian meliputi menyusun struktur organisasi bidang sarana prasarana di MI Kebonharjo Semarang Utara, menempatkan sumber daya manusia sesuai dengan kompetensi dan keahliannya, menguraikan tugas dan kewajiban serta wewenang dan haknya, bertanggungjawab untuk melaksanakan tugas pokok dan fungsi yang diamanahkannya, bekerja sama untuk berkomunikasi dan berkoordinasi dengan sumber daya manusia yang lain untuk melaksanakan tugas, tanggung jawab tersebut demi mewujudkan cita-cita MI Kebonharjo Semarang Utara.

Penggerakan meliputi mengadakan barang ketika mendesak dan penting serta harus ada tanpa melihat dari program kerja yang sudah ditentukan dan disahkan, melakukan inventarisasi dan perawatan, 
pemilihan barang yang masih layak digunakan dan yang tidak layak digunakan, penanggungjawab ruang/ kelas melaporkan kepada kepala sekolah dan diteruskan dengan melapor kepada yayasan untuk meminta keputusan tindakan lanjutan yang harus ditempuh, mendapatkan keputusan dari yayasan dengan syarat diperbaiki jika masih bisa, dan dijual jika tidak bisa lagi untuk diperbaiki.

Pengawasan meliputi melakukan koordinasi dan komunikasi dengan penanggungjawab ruang/kelas bersama kepala sekolah menentukan program, rencana program pemantauan, penjadwalan pengawasan, meminta setiap penanggungjawab ruang/kelas mencatat secara rapi dan teratur dalam buku sesuai daftarnya masing-masing, penanggungjawab berkewajiban melaporkan kegiatan kepada kepala sekolah, kepala sekolah meminta bantuan kepada pengawas madrasah untuk memantau dan menilai hasil kinerja semua guru ataupun penanggungjawab ruang atau kelas dan memberikan saran serta masukan, kepala sekolah melakukan evaluasi dan tindak lanjut supaya tidak terulang kembali di tahun depan.

Faktor pendukung manajemen sarana dan prasarana untuk mengembangkan mutu pendidikan di MI Kebonharjo Semarang Utara di antaranya perancangan yang sangat apik dilakukan oleh sumber daya manusia yang ada di MI Kebonharjo Semarang Utara, penempatan sumber daya manusia yang sesuai kompetensinya untuk menduduki jabatan, pengarsipan yang sangat rapi dan terdokumentasikan secara apik, koordinasi dan komunikasi yang terjalin baik antar sesama sumber daya manusia yang menempati posisi karena sedikitnya sumber daya manusia dan pengawas yang terlibat dalam menilai dan memberikan masukan untuk perbaikan kompetensi sumber daya manusia.

Faktor penghambat manajemen sarana dan prasarana untuk mengembangkan mutu pendidikan di MI Kebonharjo Semarang Utara di antaranya komitmen sumber daya manusia yang masih kurang di MI Kebonharjo Semarang Utara untuk merealisasikan program yang sudah disusun dan disepakati, kecenderungan melakukan kebiasaan melaksanakan program yang insidental serta sifatnya penting, mendesak dan tidak tertulis dalam program kerja sekolah, minimnya anggaran untuk mengalokasikan dan memenuhi semua kebutuhan yang dikeluarkan sekolah selama satu tahun, proses keputusan pengambilan tindakan yang harus menunggu dari kebijakan yayasan, dan kurangnya kesempatan latihan pengembangan keahlian dan kompetensi bagi sumber daya manusia yang ada.

\section{DAFTAR RUJUKAN}

Arikunto, S. 2006. Prosedur Penelitian: Suatu Pendekatan Praktik. Jakarta: PT Rineka Cipta.

Bafadal, I. 2000. Manajemen Peningkatan Mutu Sekolah Dasar: Dari Sentralisasi Menuju Desentralisasi. Jakarta: Bumi Aksara.

Handayaningrat, S. 2007. Pengantar Studi Ilmu Administrasi dan Manajemen. Jakarta: Bina Aksara.

Moeloeng, L. J. 2002. Metode Penelitian Kualitatif. Bandung: PT Remaja Rosdakarya.

Munir, \& Wahyu. 2006. Manajemen Dakwah. Jakarta: Kencana.

Nurhattati, F. M. 2018. Manajemen Sarana dan Prasarana Pendidikan: Konsep dan Aplikasinya. Depok: PT Raja Grafindo Persada.

Prastyawan. 2016. Manajemen Sarana dan Prasarana Pendidikan, (Online), (http://ejournal.kopertais4.or.id/ pantura/index.php/alhikmah/article/view/2797), diakses 2 Mei 2019.

Siagian, S. P. 2012. Fungsi-fungsi Manajemen. Jakarta: Bumi Aksara.

Sugiyono. 2012. Metode Penelitian Pendidikan. Bandung: Alfabeta.

Sulistyorini. 2009. Manajemen Pendidikan Islam: Konsep, Strategi dan Aplikasi. Yogyakarta: Teras.

Trisnawati, Cut, Z. H., \& Nasir, U. 2019. Manajemen Sarana dan Prasarana Pendidikan dalam Meningkatkan Mutu Pembelajaran di SD Negeri Lamteubee Aceh Besar. (Online), (http://jurnal.unsyiah.ac.id/JAP/article/ view/13184), diakses 2 Juli 2019. 